\title{
Needs Analysis of Training Web Exe CMS (Content Management System) and Arduino "Two In One" For Physics Teacher
}

\author{
Umi Pratiwi \\ Purworejo Muhammadiyah University, Indonesia \\ umipratiwi@umpwr.ac.id
}

Received: August $7^{\text {th }}, 2019$. Revised: September $28^{\text {th }}, 2019$. Accepted: September $30^{\text {th }}, 2019$

\section{Keywords :}

Needs Analysis; Web Exe; Arduino

\begin{abstract}
Most of physics teachers in Purworejo Regency use conventional teaching media. This is due to the lack of understanding and information about the latest It-based teaching media. They need new breakthroughs and methods to improve the quality of physics learning, especially those related to the development of teaching media. Therefore CMS (Content Management System) web exe and Arduino-based training needs analysis are conducted for Purworejo Regency physics teachers. This effort are tested by research descriptions are by giving questionnaires to respondents. The results showed that Purworejo district physics teachers needed continuous and periodic training with guided monitoring and needed training related to the latest IT-based teaching media such as e learning and microcontroller-based teaching media such as Arduino.
\end{abstract}

\section{INTRODUCTION}

Teacher as "agent of changes" is very influential in improving the quality of education. The teacher as the center of education is a noble and dignified profession [1]. The role of the teacher is very large in the world of education, it requires a qualified teacher according to the field of science [2-4]. Teachers who perform well and are qualified will also need facilities and increase in adequate and continuous competence [1]. This is necessary because education including teachers will be greatly influenced by changing times. Physics teacher is a science teacher who is strongly influenced by changing times in accordance with the development of science and technology in the era of industrial revolution 4.0. Learning of the industrial revolution era 4.0 requires preparation for innovative learning adapted to rapid technological developments and continuous network system preparation [5]. This era of learning has an impact on the application of digital technology in teaching that does not recognize space and time [6].

The quality of the physics teacher greatly influences the quality of physics learning. Physics teachers need to increase the competencies that exist within the individual's internal teacher and continue to hone skills according to the times [7]. According to Mulyasa [8] the competency standards of good and professional teachers are teachers who have the function and purpose of education according to the times. Competencies needed by physics teachers in particular are professional, pedagogic, and 
personality competencies [9]. Competencies that are directly related to learning are professional competence and pedagogical competence [10].

Pedagogic competence directly and significantly affects the success of teachers in teaching creativity by $68.9 \%$ [11]. Pedagogical enhancements to improve the creativity of physics teachers can be done by training that is right on target according to teacher needs analysis [12]. Training is an activity to improve one's work ability in relation to his profession, and understand a practical knowledge to improve the skills, skills and attitudes needed by educational goals to achieve goals [13]. This definition is in accordance with the Minister of Administrative Reform and Bureaucracy Regulation No. 16 of 2009 which is a form of increasing teacher competence.

Quality physics learning not only requires teachers' pedagogical skills in creativity but needs to be supported and collaborated with the creativity of learning media available as simulators [14]. According to Jufri [15] that Pedagogic skills are closely related to the demands of 21st Century skills, namely information capability, media and technology. Some countries have 21 st Century abilities with certain criteria, such as in Malaysia the ability of ICTs of an individual to use ICT literacy skills to solve problems in an innovative and creative way, in contrast to Australia literacy skills are marked by being able to make and share information through ICT responsibly [16].

Therefore teacher training programs using information technology are the right way to improve professional and teacher competencies [17]. Learning physics using presentation slides is not enough to provide understanding and skills to all students. So we need a new strategy in the form of the use of Information and Communication Technology (ICT) in learning. The use of ICT media provides convenience and motivation during the learning process [18]. Problems that are often encountered in the field are problems of accessibility and lack of infrastructure, which disrupts the development of learning [19]. Research conducted by Rushton, et al [20] states that physics teacher performance is strongly influenced by his educational background and experience. This is also experienced by the physics teachers who are directly related to the development of technology in learning physics. A problem that is often encountered in the field is the problem of accessibility and lack of infrastructure, which interferes with the development of learning [19].

Some of the obstacles faced by physics teachers in Purworejo district are related to the use of ICT for physics teaching media according to Pratiwi and Sriyono [21] firstly the teachers have not made maximum use of ICT technology, especially e-learning learning software, and the second teacher has low understanding and information about microcontroller-based electronic software and hardware and the use of sensors to help the learning process of physics, especially as a physics laboratory aid.

Based on this, it is necessary to analyze development needs and training for physics teachers in Purworejo Regency about the use of software and hardware (two in one) to help the process of learning physics and improving the quality of learning physics. Collaboration of software and hardware in the form of "Two in One", namely the use of CMS (Content Management System) web exe-based teaching media capable of being a good e-learning teaching media [22] and the use of Arduino microcontroller based teaching media makes learning effective [23]. Learning e-learning using CMS Web Exe is very helpful in the learning process, especially in the use of face-to-face time that is effective and efficient and easy access to information [24].

\section{METHOD}

The method used in this research is descriptive research by giving questionnaires to respondents. The study was conducted at SMA N 1 Purworejo. The time of the implementation was carried out in MayJune 2018 with the implementation carried out with 2 (two) stages, namely the first stage of the introduction stage of the theory of physics learning and its application and the second phase of short training on e-learning web eXe and arduino. The study was attended by Purworejo district physics teachers who were members of the MGMP (Musyawarah Guru Mata Pelajaran) Physics of Purworejo 
Regency totaling 18 respondents. The data obtained in this study are questionnaire data and documentation. Questionnaire data was obtained by giving questionnaires to respondents in the form of questionnaire training achievement before implementation and after implementation. The questionnaire method is a series or list of questions that are arranged systematically [25]. The type of questionnaire used is open questionnaire, which is a questionnaire that can be answered or responded freely by respondents [26]. Questionnaire data were given before the training process to find out how far the trainees' understanding and knowledge were given in the first activity. Questionnaire after training is used to determine the results of the training achievement after the training process in the second activity.

\section{RESULTS AND DISCUSSIONS}

This research is conducted to find out the responses and needs needed by physics teachers in the process of learning physics in high school. The questionnaire was given in two stages of activity. The first activity is the activity of giving material related to IT-based physics learning applications. In the first activity four items were given, namely: (1) respondents' opinions about the activity, (2) the format of activities needed by respondents, (3) material needed in training activities, (4) suggestions or inputting respondents in carrying out these activities.

The second activity is the training of making e learning and the making of microcontroller-based teaching media. The second activity was given six items of questions, namely: (1) the instructional media known to the respondents, (2) the application of e learning in physics learning, (3) respondents 'understanding of microcontrollers and sensors for physics teaching media, (4) respondents' expectations in using teaching media physics in the future, (5) the opinions of respondents in the second activity, and (6) the opinions of respondents if microcontrollers and sensors are used in physical learning.

The results of the descriptive analysis in the first activity showed that the activities were very useful to add insight into instructional media according to technological developments, regarding the activities of respondents who wanted the practice of guided training based on practice, respondents needed training material on current IT-based learning innovations, and respondents suggested that the activities be carried out continuously every semester.

In summary, can be seen in the table below.

Table 1. The results of the questionnaire implementation of e learning and IT-based teaching media

\begin{tabular}{|c|c|c|}
\hline No & Questionnaire & Results \\
\hline 1. & $\begin{array}{l}\text { Teaching media that you } \\
\text { know now }\end{array}$ & $\begin{array}{l}\text { a. Media based on android / web / e-learning ( } 80 \\
\% \text { ) } \\
\text { b. Power point ( } 20 \%)\end{array}$ \\
\hline 2. & Use of e-learning in learning & $\begin{array}{ll}\text { a. } & \text { Already applied }(0 \%) \\
\text { b. } & \text { Not yet implemented }(70 \%) \\
\text { c. } & \text { Sometimes }(30 \%)\end{array}$ \\
\hline 3. & $\begin{array}{l}\text { Knowledge of sensors as a } \\
\text { teaching media for physics }\end{array}$ & $\begin{array}{l}\text { a. Know }(0 \%) \\
\text { b. Do not know }(100 \%)\end{array}$ \\
\hline 4. & $\begin{array}{l}\text { The application of } \\
\text { microcontrollers in physics } \\
\text { teaching media }\end{array}$ & $\begin{array}{l}\text { a. All participants have never used and the training } \\
\text { adds insight to participants about IT-based media }\end{array}$ \\
\hline 5. & $\begin{array}{l}\text { Participants' suggestions for } \\
\text { this training }\end{array}$ & $\begin{array}{l}\text { a. Performed periodically }(90 \%) \\
\text { b. Developed into IoT }(10 \%)\end{array}$ \\
\hline
\end{tabular}


JIPF, Vol. 4 No. 2, September 2019

A summary of the questionnaire results to respondents can be seen in the picture below.

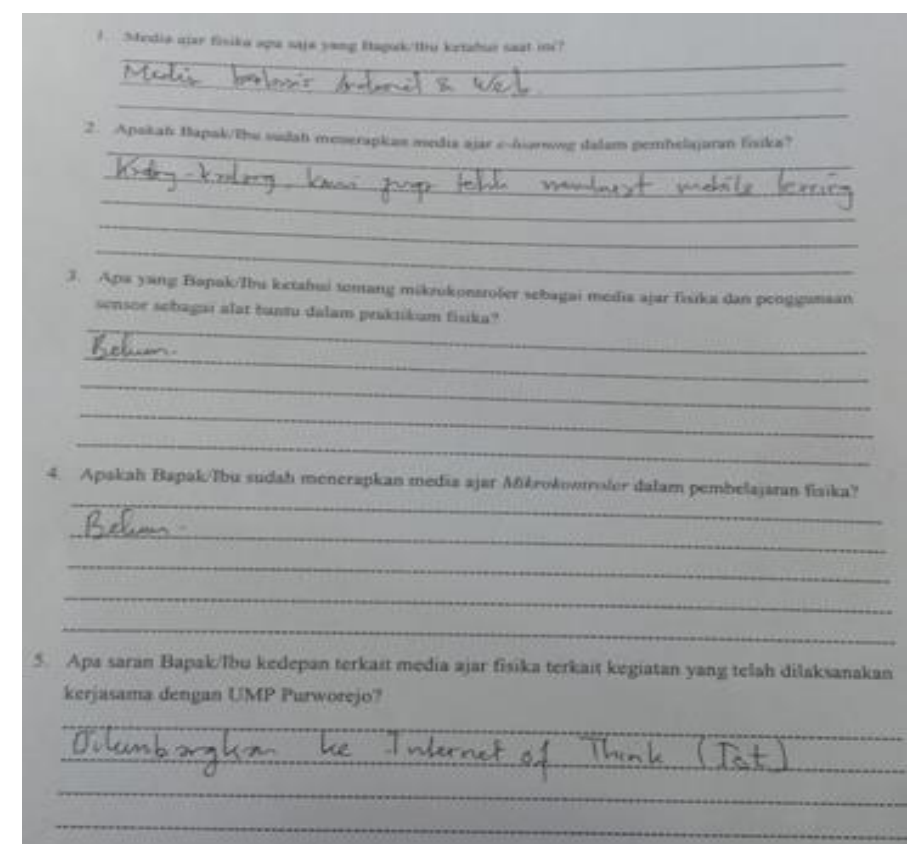

Fig 1. Examples of questionnaires filled out by respondents

The following is a graph of the analysis of the needs of the physics teacher of Purworejo Regency in the first activity The second activity is a simple material training activity for e learning web exe and Arduino programming.

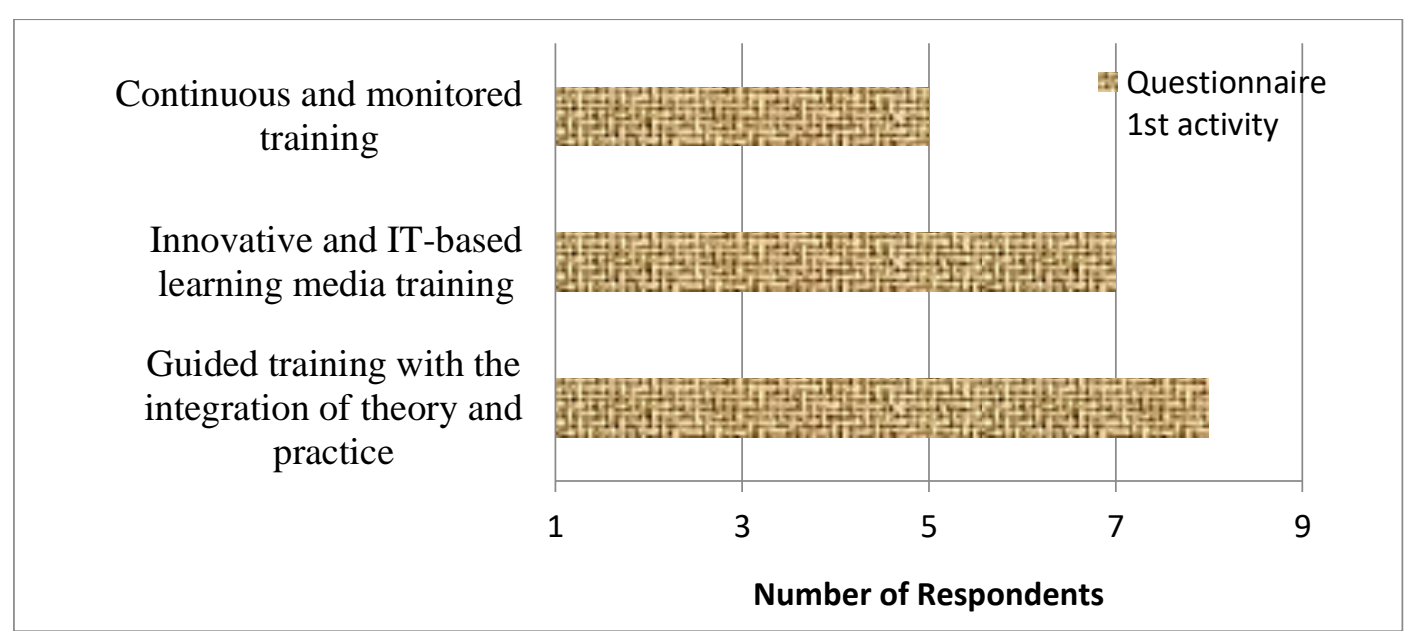

Fig 2. Questionnaire for the first activity question about the implementation of training needed by the Purworejo Regency physics teacher

In the second activity of the respondents there are still many who use power point in the implementation of learning, they are not familiar with microcontroller and censorship teaching media, and have not applied e learning learning. 


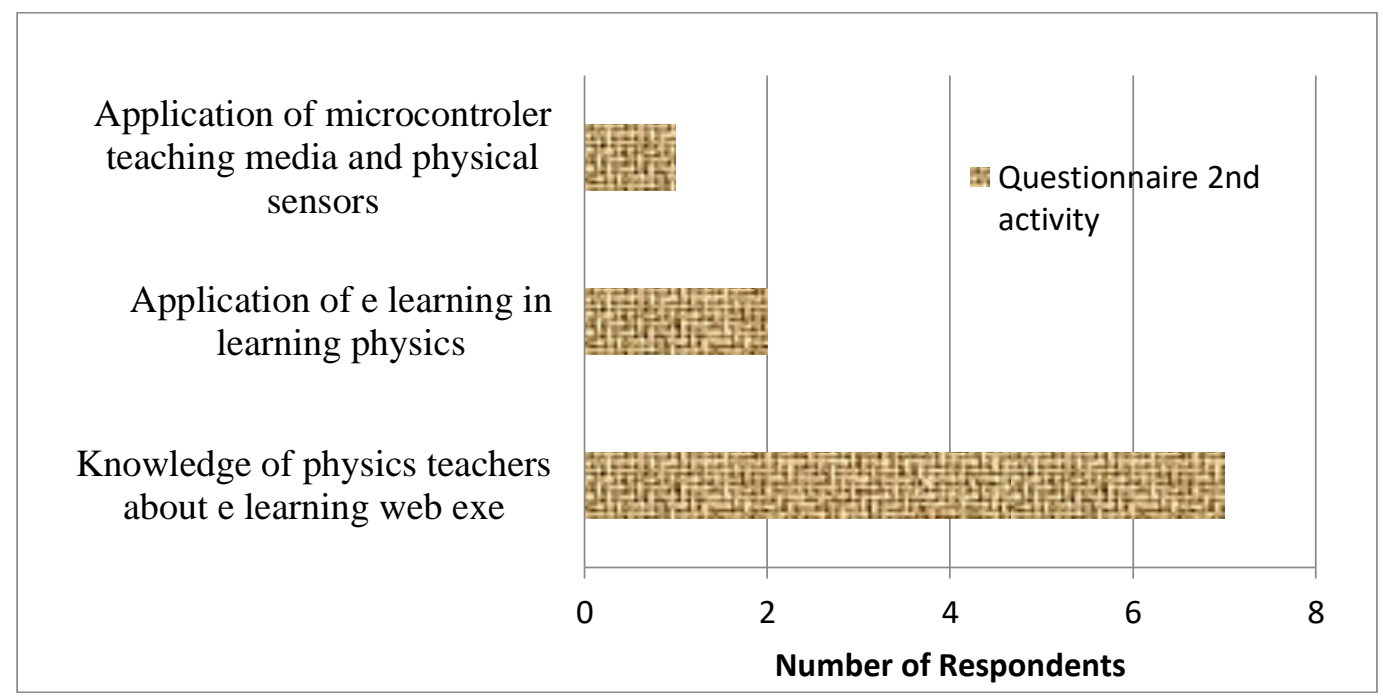

Fig 3. Questionnaire questions about the application of e-lerning and teaching media based on microcontrollers

Application of microcontroler teaching media and e learning in physics learning

usefulness of training in learning physics

The training activities are very useful and interesting

Questionnaire 2nd activity

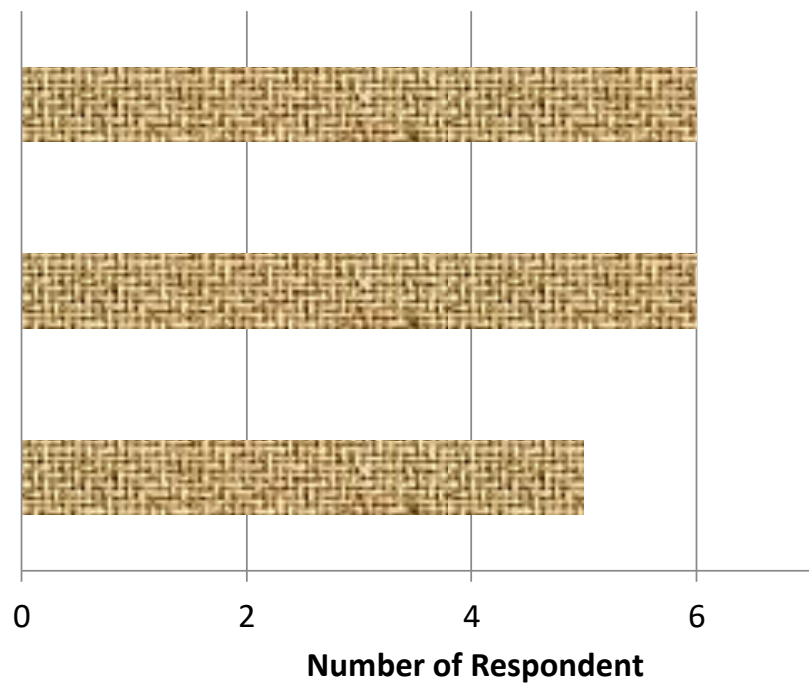

Fig 4. Questionnaire about the utilization of e-learning and teaching media based on microcontrollers to improve the quality of learning

The first activity before the training process is the provision of materials related to the latest physics learning and IT-based learning media. The first activity participants were given a questionnaire to find out the understanding of participants related to the use of IT-based learning media and its application in learning that has been done. The results of the training participants' questionnaire showed that almost $80 \%$ of participants did not know the physics learning media based on the physical sensor integrated microcontroller and as many as $70 \%$ of participants stated that they had never used the media.

The core activity in this training is located in the second activity with training in making e learning and microcontroller teaching media using Arduino for introductory material. The preliminary training in making e learning is in the form of introducing CMS, installing CMS and creating CMS content. Elearning material is delivered in stages with practice. The introduction of Exe web e-learning which is 
a CMS (Content Management System) system that provides the opportunity for teachers or instructors to create content or content in a structured manner independently, the content of the material tailored to the needs to be delivered to students. After the introduction, proceed with the installation of eXe web software on each participant's laptop guided by the speaker. The installation process has not had many difficulties, almost all participants managed to install the software. After the web exe is installed, proceed with creating the contents or contents of the web exe. Respondents did not experience difficulties when making titles, subtitles and children subtitles. The first material in this activity went well with $80 \%$ of respondents able to finish well.

The second stage material is material for making Arduino-based teaching media. First, the participants installed the Arduino IDE software on each laptop guided by the speaker. After Arduino IDE was installed, a brief description of the Arduino programmer was continued and the project was continued. The first project with making clip-clop lights using LEDs. The first project was still simple so participants did not experience difficulties. The second project increased in the manufacture of teaching media using temperature and ultrasonic sensors. Temperature sensors used to measure temperature can be applied instead of conventional thermometers. While ultrasonic sensors can be applied in distance measurements for GLB and GLBB materials such as measuring speed. Temperature measurement by practicing measurement of room temperature or room temperature of the training, the results obtained can be seen on the screen of the Arduino viewer.

The results of observations and questionnaires in the second activity with introductory e-learning and Arduino material showed that e-learning material achieved an average recall of $67 \%$ with a focus on 3 materials with material achievement $75 \%$. While the material for Arduino microcontroller-based teaching media reached an average increase of $25 \%$ with a focus on 2 materials with material achievement of $50 \%$. The graph above shows that the increase in the 1 st material is more significant than the second material. This is because the level of difficulty between material 1 and material 2 is different. The first material is an easy category material, while the second material is material with two trainings namely Arduino programming and electronic component assembly. The second material is a collaboration between software capabilities with hardware capabilities or we call "Two in One". The second material should be given separately and separately with a structured duration of training, making it easier in the learning process. In addition, the training projects provided are still the basic level not yet reaching the applicative or development level. However, the training participants felt greatly helped by the results of the questionnaire that had been filled out by the training participants.

It is hoped that this training will continue to develop similar trainings to improve the quality of futureoriented and not outdated physics learning.

The mentoring of junior high school physics teachers was also carried out in Pati in the form of a workshop on the making of Junior High School physics practicum tools, resulting in a new understanding of making practical parktikum equipment at an affordable cost and its application in learning physics [27]. In addition, it is known that an analysis of the needs needed by physics teachers, especially in Purworejo Regency. Analysis of these needs in order to improve the quality of learning. In this second activity, the focus is on the e-learning training process and the physical censorship media produces a pretty good response. The trainees gave a positive response and stated that the training was very useful and enjoyable as much as $75 \%$ of the total participants. In addition, almost $90 \%$ of participants expressed their hope to continue the training with the same theme as sustainable.

\section{CONCLUSION AND SUGGESTION}

Analysis of the need to improve the Competency of Purworejo Regency Physics Teachers through Training and Media Development on Physics Teaching Based on Web Exe and Arduino CMS (Content Management System) it can be concluded that based on research and discussion on training needs analysis based on CMS (Content Management System) web exe and arduino for Purworejo Regency physics teacher by using questionnaires and basic material training, training is needed for the 
Needs Analysis of Training Web Exe CMS (Content Management System) and Arduino... Umi Pratiwi

development of IT-based teaching media such as the use of e learning and microcontroller media and training is conducted regularly with guided monitoring.

\section{REFERENCES}

[1] Nadeem, M., Rana, M. S., Lone, A. H., Maqbool, S., Naz, K., \& Akhtar, A. (2011). Teacher's Competencies And Factors Affecting The Performance Of Female Teachers In Bahawalpur (Southern Punjab) Pakistan. International Journal of Business and Social Science, 2(19).

[2] Hamka, D., \& Suparwoto, S. (2018). Kemampuan (Kinerja) Guru Fisika SMA Negeri dalam Pembelajaran Berdasarkan Teaching Experience Di Kabupaten Kampar. Journal of Natural Science and Integration, 1(1).

[3] Shah, J., Ali, A., \& Khan, I. (2012). A critical appraisal of the social status of teachers in Peshawar, capital of Khyber Pakhtunkhwa, Pakistan. International Journal of Academic Research in Business and Social Sciences, 2(1): 176.

[4] Bakri, F., \& Budi, S. (2015). Analisis Hasil Uji Kompetensi Guru Fisika. Jurnal Penelitian \& Pengembangan Pendidikan Fisika, 1(1): 91-96.

[5] Subekt, H., Taufiq, M., Susilo, H., Ibrohim, I., \& Suwono, H. (2018). Mengembangkan Literasi Informasi Melalui Belajar Berbasis Kehidupan Terintegrasi Stem Untuk Menyiapkan Calon Guru Sains Dalam Menghadapi Era Revolusi Industri 4.0: Revieu Literatur. Education and Human Development Journal, 3(1).

[6] Sujadi, I. (2019). Peran pembelajaran matematika pada penguatan nilai karakter bangsa di era revolusi industri 4.0. Prosiding Silogisme, 1(1).

[7] Suparno, P. (2013). Miskonsepsi \& Perubahan Konsep dalam Pendidikan Fisika. Gramedia Widiasarana.

[8] Mulyasa, E. (2013). Uji kompetensi dan Penilaian Kinerja guru. Bandung: PT Remaja Rosdakarya.

[9] Cahyotlogo, B. D., \& Jumadi, J. (2017). Pemetaan Kompetensi Pedagogik, Profesional, Kepribadian dan Sosial Guru Fisika SMA di Kabupaten Kulon Progo Pascasertifikasi. Jurnal Pendidikan Fisika dan Keilmuan (JPFK), 3(2): 96-109.

[10] Wulandari, R. W., \& Mundilarto, M. (2016). Kompetensi Pedagogik Dan Profesional Guru Fisika Dalam Melaksanakan Pendekatan Saintifik Di SMAN Sleman. Jurnal Pendidikan Fisika dan Keilmuan (JPFK), 2(2): 92-104.

[11] Febrianis, I., Muljono, P., \& Susanto, D. (2014). Pedagogical competence-based Training Needs Analysis for Natural Science Teachers. Journal of Education and Learning, 8(2): 144-151.

[12] Sunarno, W., Wiyono, E., \& Raharjo, T. (2015). Pelatihan dan Peningkatan Kompetensi Pembelajaran IPA yang Berbasis Komputer (Ict) Bagi Guru IPA SMP di Karanganyar. In Prosiding SNPS (Seminar Nasional Pendidikan Sains) (Vol. 2, pp. 309-317).

[13] Putri, S. A., \& Warianto, W. (2017). Pengaruh Pelatihan dan Kalimat Motivasi Terhadap Produktifitas Kerja Karyawan UMKM. Optima, 1(1): 60-71.

[14] Bantwini, B. (2017). Analysis of teaching and learning of natural sciences and technology in selected Eastern Cape province primary schools, South Africa. Journal of Education, (67): 39-64.

[15] Jufri, A. W. (2018). Peningkatan Kompetensi Guru IPA Kota Mataram dalam Memfasilitasi Penguasaan Keterampilan Abad Ke 21 Siswa SMP. Jurnal Pengabdian Magister Pendidikan IPA, 1(1): 1-6.

[16] Thammasaeng, P., Pupat, P., \& Phetchaboon, S. (2016). Needs assessment of information and communication technology literacy (ICT Literacy) of students in secondary educational service area. International Journal of Emerging Technologies in Learning (iJET), 11(12): 9-13. 
[17] Fajar, M. Y., Rohaeni, O., Permanasari, Y., \& Mulkiya, K. (2017). Meningkatkan Kompetensi Guru SMA dan Sederajat Melalui Pelatihan Pembelajaran berbasis TIK. ETHOS (Jurnal Penelitian dan Pengabdian), 5(2): 175-181.

[18] Yusuf, I., \& Widyaningsih, S. W. (2018). Implementasi Pembelajaran Fisika Berbasis Laboratorium Virtual terhadap Keterampilan Proses Sains dan Persepsi Mahasiswa. Berkala Ilmiah Pendidikan Fisika, 6(1): 18-28.

[19] Khairi, A., \& Danil, M. (2015). Kemampuan Pembelajaran Berbasis TIK Pada Guru SMP di Kota Padang Dalam Menyambut Implementasi Kurikulum 2013. Jurnal ipteks terapan, 8(04).

[20] Rushton, G. T., Rosengrant, D., Dewar, A., Shah, L., Ray, H. E., Sheppard, K., \& Watanabe, L. (2017). Towards a high quality high school workforce: A longitudinal, demographic analysis of US public school physics teachers. Physical Review Physics Education Research, 13(2): 020122.

[21] Pratiwi, U., \& Sriyono, S. (2018). Meningkatkan Kompetensi Guru Fisika dengan Model STM "Two in One" Melalui Pelatihan dan Pengembangan Media Ajar Fisika Berbasis CMS (Content Management System), Web EXE dan Arduino di Kabupaten Purworejo. Journal of Dedicators Community, 2(2): 123-133.

[22] Fauziah, F. (2012). Pengembangan Bahan Ajar Berbasis Web Menggunakan Exe (E-Learning XHTML Editor) Pokok Bahasan Bangun Ruang Kubus dan Balok Kelas VIII SMPN 3 Kuningan (Doctoral dissertation, IAIN Syekh Nurjati Cirebon).

[23] Haryawan, A., \& Salechan, S. (2017, November). Pengembangan Bahan Ajar Mikrokontroler Berbasis Arduino sebagai Media Pembelajaran Mata Kuliah Mikrokontroler di Politeknik Pratama Mulia Surakarta. In Prosiding Seminar Nasional Teknologi Informasi dan Bisnis 2017 (pp. 207214).

[24] Yulita, A. R., Ambarwulan, D., \& Bakri, F. (2018). Pengembangan E-Learning Menggunakan Chamilo Untuk Membantu Proses Pembelajaran Fisika SMA Kelas X Semester II. Gravity: Jurnal Ilmiah Penelitian dan Pembelajaran Fisika, 4(2).

[25] Bungin, Burhan. (2011). Metodologi penelitian Kuantitatif. Jakarta: Penerbit Kencana.

[26] Widoyoko, E. P. (2012). Teknik Penyusunan Instrumen Penelitian. Yogyakarta: Pustaka Pelajar.

[27] Anwar, E. D. (2016). Pelatihan Pembuatan Alat-Alat Praktikum IPA Fisika Bagi Guru IPA SMP/MTS Swasta Sekecamatan Winong Kab Pati. Dimas: Jurnal Pemikiran Agama untuk Pemberdayaan, 14(1): 43-56. 